\title{
PERBEDAAN SOSIALISASI NILAI PERTANIAN OLEH AGEN SOSIALISASI PRIMER KEPADA PEMUDA DAN PEMUDI DI PEDESAAN (KASUS DESA CIASMARA, PAMIJAHAN, BOGOR)
}

\author{
Yogaprasta Adi Nugraha*, Muslim
}

\author{
Fakultas Ilmu Sosial dan Ilmu Budaya, Universitas Pakuan Bogor \\ Jl. Pakuan, RT.02/RW.06, Tegallega, Bogor Tengah, Bogor 16129 \\ *Corresponding author: yogaprasta_adinugraha@unpak.ac.id
}

\begin{abstract}
The phenomenon related to the low participation of young people to work in the agricultural sector, it is necessary to be studied more new perspectives. Moreover, the perspective of how agriculture itself is constructed by their social system, in this case, how parents and peers construct the notion of agriculture. The objectives of this study are 1) to identify the differences between the attitudes of male and female rural youth towards work in the agricultural sector, 2) to analyze differences in the patterns of socialization of parents and peers to male and female rural-youth about work in the agricultural sector, and 3) analyze the differences between the relationship patterns of socialization of parents and peers with the attitude of male and female rural youth towards agricultural work. This research was conducted in Ciasmara Village, Pamijahan Sub-district, Bogor District from July 2019 to February 2020 using quantitative research methods with a descriptive-comparative approach. A total of 69 young women and 60 young people were selected as research samples. This study found that there were differences in attitudes between male and female rural youth related to work in the rice agriculture sector. Parents were the actors who most highly socialize the value of agriculture to young men and women in the form of involving the activities of growing rice, cultivating land, and harvesting. Meanwhile, both parents and peers have positively correlated with the attitudes of young men and women about work in the agricultural sector.
\end{abstract}

Keywords: agricultural work, female rural-youth, male rural-youth, parents, peers

Abstrak: Fenomena mengenai rendahnya partisipasi orang muda untuk bekerja di
sektor pertanian perlu dikaji secara lebih komprehensif dari sudut pandang bagaimana
pertanian itu sendiri dikonstruksi oleh sistem sosial terdekat mereka dalam hal ini
adalah orang tua dan teman sepermainan. Beberapa studi telah menjelaskan bahwa
sistem sosial pemuda memiliki pengaruh yang sangat kuat dalam membangun nilai
pertanian. Penelitian ini bertujuan untuk 1) mengidentifikasi perbedaan antara sikap
pemuda dan pemudi terhadap pekerjaan di sektor pertanian di desa, 2) menganalisis
perbedaan pola sosialisasi orang tua dan teman sepermainan kepada pemuda dan
pemudi tentang pekerjaan di sektor pertanian, dan 3) menganalisis perbedaan antara
hubungan pola sosialisasi orang tua dan teman sepermainan dengan sikap pemuda -
pemudi terhadap pekerjaan di sektor pertanian di desa. Penelitian ini dilakukan di
Desa Ciasmara, Kecamatan Pamijahan, Kabupaten Bogor dari Juli 2019 sampai
Februari 2020 dengan mengunakan metode penelitian kuantitatif dengan pendekatan
deskriptif-komparatif. Sebanyak 69 pemudi dan 60 pemuda terpilih sebagai sampel
penelitian. Penelitian ini menemukan bahwa terdapat perbedaan sikap antara pemuda
dan pemudi terkait pekerjaan di sektor pertanian padi, orang tua merupakan aktor yang
paling tinggi menyosialisasikan nilai pertanian kepada pemuda dan pemudi dalam
bentuk pelibatan kegiatan menanam padi, mengolah lahan, dan panen. Sementara itu, 
baik orang tua dan teman sepermainan memiliki hubungan positif terhadap sikap pemuda dan pemudi terkait pekerjaan di sektor pertanian.

Kata kunci: pekerjaan di sektor pertanian, pemuda desa, pemudi desa, orang tua, teman sepermainan

\section{PENDAHULUAN}

Saat ini Indonesia tengah mengalami permasalahan terkait kesempatan kerja untuk pemuda sama seperti berbagai negara di belahan dunia lainnya Berdasarkan statistik Indonesia (2017), jumlah pemuda pengangguran (15-24 tahun) dua kali lebih tinggi dibandingkan dengan orang dewasa, sementara itu berdasarkan Sensus pertanian 2013, sektor pertanian terutama sektor pertanian rakyat masih menjadi penyerap tenaga kerja tertinggi jika dibandingkan dengan sektor lain, meski jumlahnya cenderung menurun menjadi 40 persen dari seluruh angkatan kerja di tahun 2013. Dari total 40\% angkatan kerja yang bekerja di sektor pertanian, sebanyak $24,7 \%$ bekerja di sektor pertanian padi dan palawija. Jika dikaji secara lebih mendetail, kita dapat melihat bahwa pekerjaan di sektor pertanian masih menjadi penyerap terbesar bagi tenaga kerja di sektor pertanian. Sebanyak 32\% dari semua angkatan kerja muda dan 54\% dari angkatan kerja muda di desa (BPS, 2013). Namun, dalam 10 tahun terakhir, jumlah rumah tangga petani di Indonesia menurun dengan cepat, penurunannya dapat mencapai 5 juta rumah tangga penduduk. Berdasarkan situasi ini maka, terdapat fakta bahwa tidak terjadi regenerasi pekerja di sektor pertanian dan orang muda tidak tertarik untuk bekerja di sektor pertanian.

Sektor pertanian merupakan sektor yang memiliki kontribusi positif terhadap pendapatan nasional, namun selain berkontribusi terhadap pendapatan nasional, sektor pertanian juga mampu menjadi sektor yang mampu menyerap tenaga kerja terutama tenaga kerja di pedesaan (Nugraha dan Herawati, 2015). Urgensi sektor pertanian tidak serta merta sejalan dengan proses regenerasi pekerja dan kesejahteraan petani. Permasalahan mengenai regenerasi pekerja pertanian telah menjadi pembahasan penting dalam beberapa dekade terakhir, seperti yang telah dilakukan oleh White (2012). Sementara itu Akatiga dan White (2015) mengatakan bahwa sektor pertanian merupakan sektor yang penting karena selain mampu berkontribusi terhadap pendapatan nasional, sektor pertanian juga mampu menyerap tenaga kerja saat semua sektor sedang buruk kinerjanya. Pemuda memiliki peranan penting sebagai penerus keberlangsungan sektor pertanian. Rendahnya partisipasi orang muda di sektor pertanian menjadi ancaman tersendiri bagi ketahanan pangan di masa yang akan datang. Hilangnya regenerasi pertanian dapat menyebabkan lost generation of farmers, kondisi ini akan berdampak terhadap produksi pertanian dan keberlanjutan pertanian. Sehingga dapat menjadi ancaman bagi ketahanan pangan bangsa Indonesia (Nugraha, 2012).

Terdapat banyak faktor yang menyebabkan orang muda di desa tidak bekerja di sektor pertanian. Beberapa studi sebelumnya yang dilakukan oleh White (2020), dan Nugraha dan Supriatna (2020a) menyebutkan bahwa perginya orang muda dari sektor pertanian disebabkan, 1) orang muda tidak memiliki akses terhadap tanah, 2) sistem sekolah yang cenderung menggambarkan pertanian secara negative, 3) permasalahan dengan citra pertanian 4) sistem sosial yang cenderung tidak mendukung orang muda untuk bekerja di sektor pertanian. Meski terdapat berbagai faktor yang membuat orang muda desa tidak mau bertani, namun studi ini akan fokus terhadap bagaimana citra pertanian tersebut dibentuk oleh sistem. Citra pertanian atau pekerjaan di pedesaan tidak terlepas dari bagaimana sistem sosial di desa membangun atau membingkai pekerjaan tersebut. Akatiga dan White (2015) menjelaskan bahwa salah satu problem mendasar dari perginya orang muda dari sektor pertanian adalah pertanian yang tidak bergengsi. Untuk memahami problematika mengenai pekerjaan pertanian yang tidak bergengsi maka perlu untuk melihat bagaimana posisi agen sosialisasi primer terdekat orang muda dalam menyosialisasikan nilai - nilai pertanian. Agen sosialisasi primer yang dimaksud dalam penelitian ini adalah teman sepermainan dan orang tua sebagai aktor 
terdekat dengan orang muda di pedesaan. Nugraha dan Supriatna (2020b) telah menjelaskan bagaimana peranan ritual pertanian membangun citra pertanian, namun belum ada riset yang mencoba melihat secara detail mengenai perbedaan orang tua dalam menyosialisasikan nilai pertanian kepada anak laki - laki dan anak perempuan. Beberapa penelitian menyebutkan bahwa terdapat perbedaan dalam hal partisipasi pemuda dan pemudi dalam kegiatan pertanian, misalnya di wilayah Sulawesi Selatan, perempuan cenderung tidak ikut bertani sementara itu di Jawa, perempuan cenderung ikut bertanipada tahapan menanam maupun panen. Nugraha dan Supriatna (2020b) juga menjelaskan bahwa terdapat perbedaan pola praktek pertanian antara anak perempuan dan laki - laki, anak perempuan banyak membantu orang tuanya dengan cara mengantarkan makanan siang kepada orang tua mereka di sawah dan terkadang ikut membantu panen, dan anak lakilaki ikut bekerja membantu mengolah lahan dan panen. Perbedaan partisipasi antara lakilaki dan perempuan ini mendasari pentingnya riset mengenai bagaimana sistem sosial membangun gagasan mengenai pertanian kepada pemuda dan pemudi desa.

Fenomena mengenai rendahnya partisipasi orang muda untuk bekerja di sektor pertanian perlu dikaji secara lebih komprehensif dari sudut pandang bagaimana pertanian itu sendiri dikonstruksi oleh sistem sosial terdekat mereka. Beberapa studi telah menjelaskan bahwa sistem sosial pemuda memiliki pengaruh yang sangat kuat dalam membangun nilai pertanian. Namun, belum terdapat studi yang melihat perbedaan pola sosialisasi nilai pertanian kepada pemuda dan pemudi. Berangkat dari kondisi tersebut maka penelitian ini bertujuan untuk melihat perbedaan sikap pemuda dan pemudi terhadap pekerjaan di sektor pertanian dan perbedaan sistem sosial utama (dalam hal ini orang tua dan teman) dalam membentuk sikap pemuda dan pemudi terhadap pekerjaan di bidang pertanian. Secara lebih mendetail, pertanyaan penelitian yang coba untuk di jawab dalam studi kali ini adalah:

1. Apakah terdapat perbedaan antara sikap pemuda dan pemudi terhadap pekerjaan di sektor pertanian di Desa Ciasmara,
Kecamatan Pamijahan, Kabupaten

Bogor?

2. Apakah terdapat perbedaan pola sosialisasi orang tua dan teman sepermainan kepada pemuda dan pemudi tentang pekerjaan di sektor pertanian di Desa Ciasmara, Kecamatan Pamijahan, Kabupaten Bogor?

3. Apakah terdapat perbedaan antara hubungan antara pola sosialisasi orang tua dan teman sepermainan dengan sikap pemuda pemudi terhadap pekerjaan di sektor pertanian di Desa Ciasmara, Kecamatan Pamijahan, Kabupaten Bogor?

\section{METODE PENELITIAN}

Penelitian ini telah dilaksanakan di Desa Ciasmara, Kecamatan Pamijahan, Kabupaten Bogor. Desa Ciasmara dipilih karena beberapa pertimbangan, antara lain merupakan salah satu sentra pertanian padi di Kabupaten Bogor, dan terletak di antara pusat-pusat garmen/tekstil yang banyak menyerap tenaga kerja muda (Jayawinangun dan Nugraha, 2018). Penelitian ini merupakan bagian dari studi besar tentang pola pewarisan nilai pertanian, yang telah dilaksanakan pada Juli 2019 sampai dengan Februari 2020. Populasi dalam penelitian ini adalah orang muda yang berusia 15-24 tahun, belum menikah, bersekolah dan berasal dari keluarga petani, berdasarkan data Desa Ciasmara terdapat sekitar 1290 orang pemuda sebagai populasi penelitian, sehingga melalui metoda pengambilan sampel menurut Neuman (2014), terpilih 129 orang muda dengan rincian 69 pemudi dan 60 pemuda sebagai sampel penelitian.

Penelitian ini menggunakan metode deskriptif dengan pendekatan komparatif. Deskriptif yang dimaksud dalam penelitian ini adalah gambaran mengenai sikap pemuda dan pemudi terhadap pekerjaan di sektor pertanian dan gambaran mengenai pola sosialisasi orang tua dan teman dalam membentuk nilai pertanian. Sementara itu pendekatan komparatif yang dimaksud adalah melihat perbedaan sikap antara pemuda dan pemudi terhadap pekerjaan di sektor pertanian dan perbedaan pola sosialisasi nilai pertanian kepada pemuda dan pemudi yang dilakukan oleh sistem sosial orang tua dan teman sepermainan. 
Nugraha, Y. A., Muslim : Perbedaan Sosialisasi Nilai Pertanian ....

$\underline{\text { Tabel 1. Sebaran responden berdasarkan tingkat pendidikan }}$

\begin{tabular}{lcccc}
\hline \multirow{2}{*}{$\begin{array}{c}\text { Tingkat Pendidikan } \\
\text { Terakhir }\end{array}$} & \multicolumn{2}{c}{ Pemuda } & \multicolumn{2}{c}{ Pemudi } \\
\cline { 2 - 5 } & Frekuensi & $\begin{array}{c}\text { Persentase } \\
(\%)\end{array}$ & $\begin{array}{c}\text { Frekuensi } \\
\text { (Orang) }\end{array}$ & $\begin{array}{c}\text { Persentase } \\
(\%)\end{array}$ \\
\hline Lulus SLTA & 1 & 1.7 & 0 & 0 \\
Lulus SLTP & 33 & 55 & 43 & 62,3 \\
Lulus SD & 26 & 43.3 & 26 & 37,7 \\
Total & 60 & 100 & 69 & 100 \\
\hline
\end{tabular}

Sumber: Analisis Data Primer, 2020

Analisis deskriptif yang digunakan dalam penelitian ini berupa tabulasi deskriptif yang berisi frekuensi, persentase, dan rataan skor dari sikap pemuda dan pemudi terhadap pekerjaan di sektor pertanian dan tingkat partisipasi pemuda dan pemudi dalam membantu orang tua di sektor pertanian, dan tingkat partisipasi pemuda dan pemudi dalam berinteraksi dengan teman sepermainan di sektor pertanian. Analisis inferensia yang akan digunakan dalam penelitian ini adalah uji beda (Independent t-test) untuk melihat perbedaan sikap dan pola sosialisasi dari orang tua dan teman sepermainan terhadap pemuda dan pemudi di Desa Ciasmara, Kecamatan Pamijahan, Kabupaten Bogor.

\section{HASIL DAN PEMBAHASAN}

\section{Karakteristik Pemuda dan Pemudi Desa Ciasmara}

Tingkat pendidikan dalam penelitian ini didefinisikan sebagai pendidikan formal terakhir yang dijalani oleh orang muda di desa Ciasmara, Kecamatan Pamijahan, Kabupaten Bogor. Dari Tabel 1 dapat dilihat bahwa mayoritas responden penelitian, baik pemuda dan pemudi telah lulus pendidikan Sekolah Lanjutan Tingkat Pertama (SLTP) yang berarti saat ini mereka sedang duduk di bangku pendidikan Sekolah Menengah Tingkat Atas (SLTA) dengan persentase pemuda (55\%) dan pemudi (62,3\%). Sementara itu sebagian kecil responden saat ini masih duduk di bangku Sekolah Lanjutan Tingkat Pertama (SLTP) atau pendidikan terakhir lulus sekolah dasar dengan persentase pemuda $(43,3 \%)$ dan pemudi $(37,7)$.

\section{Tingkat Pendidikan}

Penelitian ini memfokuskan kepada orang muda yang berusia 15 - 24 tahun, berdasarkan informasi dari Sekretaris Desa Ciasmara, sejak tahun 2010 pemuda di Desa Ciasmara sudah memiliki tingkat partisipasi terhadap sekolah sampai dengan tingkat SLTA karena sejak tahun 2010 terdapat sekolah setara SLTA. Sejalan apa yang dikatakan oleh (Supriatna dan Nugraha, 2020), yang mengatakan bahwa saat ini terjadi kemajuan tingkat pendidikan jika dibandingkan dengan generasi terdahulu. Hal ini disebabkan awal mulanya fasilitas pendidikan di Desa Ciasmara hanya sampai dengan tingkat SLTP, sehingga jika siswa ingin melanjutkan ke SLTA terdekat mereka harus bersedia menempuh jarak $15 \mathrm{~km}$ dari Desa Ciasmara. Kemudian, baru pada tahun 2005 dibangun sekolah setara SLTA, sampai sekarang terdapat dua sekolah setara SLTA yaitu SMA Muhammadiyah Pamijahan dan SMK Bumi Putera. Sementara itu Nugraha dan Nugroho (2019) juga menjelaskan bawa dalam satu dekade terakhir ini aksesibilitas pendidikan di desa Ciasmara telah berubah, dimana telah banyak bermunculan sekolah setingkat SLTA di desa.

Jika dibandingkan secara lebih mendetail antara pemudi dan pemuda, maka terlihat bahwa persentase perempuan bersekolah di level pendidikan yang lebih tinggi memiliki kecenderungan lebih tinggi dibandingkan dengan laki-laki. Hal ini dikarenakan, banyak pemuda selepas SLTP memilih untuk merantau ke keluar desa Ciasmara, diantaranya, banyak yang bekerja sebagai tukang sate pikul (Desa Ciasmara merupakan salah satu sentra tukang sate pikul di Kabupten Bogor) atau memilih kerja di pabrik karena menurut salah satu respoden, Iduy (28 tahun) mengatakan bahwa terdapat pabrik yang menerima pekerja lakilaki dengan usia 15 tahun dengan pendidikan minimum telah lulus SLTP.

\section{Status Kepemilikan Tanah}

Kepemilikan sawah orang tua dalam penelitian ini didefinisikan sebagai status sawah yang dimiliki oleh orang tua dari orang muda. 
Terdapat dua status kepemilikan sawah, yaitu memiliki sawah dan tidak memiliki sawah. Tabel 2 menjelaskan bahwa mayoritas orang muda di Desa Ciasmara, orang tua mereka memiliki sawah sendiri, sekitar $75 \%$ orang tua pemuda memiliki sawah sendiri sementara itu sekitar 63,8 persen orang tua pemudi memiliki sawah sendiri. Temuan tersebut mengindikasikan bahwa sebagian besar orang tua pemuda di Desa Ciasmara merupakan petani pemilik lahan. Desa Ciasmara merupakan salah satu lumbung padi Kabupaten Bogor yang mampu mengirimkan hasil panennya ke luar desa, terutama ke wilayah Jakarta dan Bekasi. Bahkan di Desa Ciasmara terdapat satu komunitas, yang bernama Komunikas Ceritakeuweh yang sudah mampu memproduksi beras dengan merek sendiri yaitu BHS (Babakan Haji Sawah). Menurut penuturan dari salah satu anggota komunitas tersebut, setiap panen mereka rutin mengirimkan ke Jakarta dan Sukabumi. Kepala Desa Ciasmara sendiri menuturkan bahwa sebagian besar sawah di desa Ciasmara masih dimiliki oleh petani itu sendiri, memang terdapat juga sawah yang bukan dimiliki oleh petani itu sendiri, petani hanya mengolah lahan dengan sistem bagi hasil atau menyewa lahan dengan sistem “Gedeng”. Namun, sekalipun terdapat sawah yang dimiliki oleh bukan petani itu sendiri, pemilik sawah tersebut masih berasal dari dalam desa Ciasmara sehingga perputaran uang yang terjadi masih di dalam desa Ciasmara.

\section{Sikap Pemuda dan Pemudi terhadap Pekerjaan di Sektor Pertanian}

Pada penelitian ini, sikap orang muda didefinisikan sebagai evaluasi orang muda terhadap tingkat kognitif, afektif, dan psikomotorik yang berkaitan dengan pekerjaan di sektor pertanian. Tingkat kognitif didefinisikan dengan pengetahuan orang muda desa terhadap praktik pertanian padi, sementara itu afeksi didefinisikan sebagai perasaan suka atau tidak suka orang muda terhadap sektor pertanian, sementara itu psikomotorik dilihat sebagai ketertarikan orang muda untuk bekerja di sektor pertanian. Secara umum dapat dilihat pada Tabel 3 bahwa secara keseluruhan, pemuda cenderung memiliki sikap yang cukup positif terhadap pekerjaan di sektor pertanian dengan nilai rataan skor 2,57 sementara pemudi memiliki sikap yang negatif terhadap pekerjaan di sektor pertanian dengan rataan skor 2,49. Apabila dikaji lebih detail dari masing-masing indikator, terdapat perbedaan yang sangat signifikan antara tingkat kognitif pemuda dengan pemudi dan tingkat psikomotorik pemuda dan pemudi terhadap pekerjaan di sektor pertanian.

Tabel 2. Kepemilikan lahan pemuda dan pemudi berdasarkan kepemilikan lahan orang tua

\begin{tabular}{lcccc}
\multirow{2}{*}{$\begin{array}{c}\text { Kepemilikan Sawah Orang } \\
\text { Tua }\end{array}$} & \multicolumn{2}{c}{ Pemuda } & \multicolumn{2}{c}{ Pemudi } \\
\cline { 2 - 5 } & $\begin{array}{c}\text { Frekuensi } \\
\text { (Orang) }\end{array}$ & $\begin{array}{c}\text { Persentase } \\
\text { (\%) }\end{array}$ & $\begin{array}{c}\text { Frekuensi } \\
\text { (Orang) }\end{array}$ & $\begin{array}{c}\text { Persentase } \\
(\%)\end{array}$ \\
\hline Memiliki Sawah & 45 & 75 & 44 & 63,8 \\
Tidak Memiliki Sawah & 15 & 25 & 25 & 36,2 \\
Total & 60 & 100 & 69 & 100 \\
\hline
\end{tabular}

Sumber: Analisis Data Primer, 2020

Tabel 3. Sikap pemuda dan pemudi terhadap pekerjaan di sektor pertanian

\begin{tabular}{lccc}
\hline \multirow{2}{*}{ Sikap } & \multicolumn{2}{c}{ Rataan Skor $^{\mathrm{a}}$} & \multirow{2}{*}{ Uji Beda $^{\mathrm{b}}$} \\
\cline { 2 - 3 } & Pemuda & Pemudi & \\
\hline Kognitif & 2,68 & 2,83 & $0,021^{* *}$ \\
Afektif & 2,60 & 2,63 & 0,732 \\
Psikomotorik & 2,44 & 2,01 & $0,00^{* *}$ \\
\multicolumn{1}{r}{ Total } & 2,57 & 2,49 & \\
\hline
\end{tabular}

Keterangan:

a: 1 - 1,75: Sangat Rendah; 1,76 - 2,51: Rendah; 2,52 - 3,27: Cukup Tinggi; 3,28 - 4: Tinggi.

b: *Berbeda Nyata, ** Berbeda Sangat Nyata 
Untuk tingkat kognitif, pengetahuan teknis pertanian pemudi cenderung lebih tinggi jika dibandingkan dengan pemuda. Hal ini disebabkan oleh beberapa faktor, antara lain adalah pemudi cenderung mengetahui secara teori tentang tata cara pertanian dan prinsip dasar bertani dari obrolan dengan bapak atau ibu mereka di rumah, sementara itu pemuda secara teori mengetahui tetapi banyak yang bertentangan cara praktik ketika mereka membantu orang tua mereka, seperti pemudi sangat tahu bahwa penggunaan pestisida itu berbahaya, sementara itu pemuda cenderung tidak tahu karena pada praktiknya pestisida masih sering digunakan dalam kegiatan bertani. Selain itu, pemudi cenderung tahu mengenai pentingnya penentuan musim tanam sementara pemuda cenderung tidak mengetahui karena mereka hanya mengikuti perintah orang tua ketika membantu di sawah. Pada dasarnya pemuda memiliki pengetahuan mengenai teknis pertanian namun, pengetahuan ideal tentang pertanian yang mereka peroleh sering kali berbenturan dengan pengetahuan-pengetahuan yang mereka peroleh saat mereka praktik. Pemudi memperoleh pengetahuan tentang pertanian dari orang tua mereka saat berkumpul keluarga dan saat mengantarkan makanan kepada orang tua mereka di sawah.

Perbedaan siginifikan juga terlihat pada tingkat psikomotorik pemuda dan pemudi. Secara umum, baik pemuda ataupun pemudi di Desa Ciasamara memiliki psikomotorik yang rendah terhadap pekerjaan di sektor pertanian hal ini mengindikasikan bahwa pemuda dan pemudi cenderung tidak tertarik untuk bekerja di sektor pertanian. Namun, ketika dibandingkan antara pemuda dan pemudi, maka pemuda cenderung lebih tertarik $(2,44)$ bekerja di sektor pertanian dibandingkan dengan pemudi $(2,01)$. Pemuda cenderung tertarik dibandingkan pemudi karena beberapa faktor, antara lain di Desa Ciasmara, pemuda sering ikut terlibat dalam membantu orang tua mereka sebagai tenaga kerja dalam keluarga atau family labor. Selain itu, banyak pemuda di desa masih sering terlibat dalam kegiatan bertani sehingga pemuda tidak malu untuk ikut bertani membantu orang tua mereka.

\section{Pola Sosialisasi Nilai Pertanian Kepada Pemuda dan Pemudi di Pedesaan}

Aktor sosialisasi dalam penelitian ini didefinisikan sebagai pihak terdekat dari orang muda yang memberikan informasi terkait bidang pertanian. Penelitian ini membatasi hanya kepada dua aktor terdekat yaitu orang tua dan teman sepermainan (Darling, 2007). Dari Tabel 4 dapat dilihat bahwa terdapat perbedaan antara pola sosialisasi orang tua dan teman sepermainan terhadap pemuda dan pemudi di desa Ciasmara.

Menurut Nugraha (2012), Valdiani et al. (2017), Nugraha dan Supriatna (2020), dan Nugraha dan Martha (2020), terdapat beberapa jenis pola sosialisasi yang dilakukan oleh orang tua dan teman sepermainan dalam memperkenalkan nilai pertanian. Orang tua menyosialisasikan nilai pertanian melalui pelibatan sebagai tenaga kerja dalam keluarga, sedangkan teman sepermainan menyosialisasikan nilai pertanian melalui kegiatan bersama terkait pertanian.

Tabel 4. Perbedaan pola sosialisasi nilai pertanian oleh orang tua dan teman

\begin{tabular}{lccc}
\hline \multicolumn{1}{c}{$\begin{array}{c}\text { Aktor } \\
\text { Sosialisasi }\end{array}$} & \multicolumn{2}{c}{ Rataan Skor $^{\mathrm{a}}$} & \multirow{2}{*}{ Uji Beda $^{\mathrm{b}}$} \\
\cline { 2 - 3 } Teman & Pemuda & Pemudi & \multirow{2}{*}{0,501} \\
Cari Informasi & 2,53 & 2,46 & \\
Berbincang ttg Pertanian & 2,37 & 2,35 & \\
Bertani Bersama & 2,34 & 2,90 & $0,00^{* *}$ \\
\hline Orang Tua & 2,60 & 1,96 & \\
Mengolah Tanah dan Tanam & 2,39 & 1,77 & \\
Panen Padi & 2,81 & 2,14 & \\
\hline a: 1 - 1,75: Tidak Pernah; 1,76 - 2,51: Jarang; $2,52-3,27:$ Cukup Sering; 3,28 - 4: Sering. \\
b: *Berbeda Nyata, ** Berbeda Sangat Nyata
\end{tabular}




\section{Pola Sosialisasi Teman Sepermainan}

Pola sosialisasi nilai pertanian antara orang muda dengan teman sepermainan dilihat dari interaksi dalam kegiatan mencari informasi tentang pertanian, berdiskusi tentang pertanian dan kegiatan bertani bersama di sawah. Tabel 4 menunjukan bahwa penelitian ini menemukan bahwa pemuda memiliki interaksi yang cukupsering dengan teman sepermainan dalam kegiatan pertanian dengan rataan skor 2,53, berbeda dengan pemudi yang cenderung jarangberinteraksi dengan teman sepermainan terkain pekerjaan di sektor pertanian dengan rataaan skor 2,46. Baik pemuda dan pemudi memiliki interaksi yang cukup sering terkait mendiskusikan kegiatan pertanian bersama dengan nilai rataan skor 2,88 dan 2,90, hal ini juga diutarakan oleh salah satu responden bahwa mereka cukup sering berbincang atau berdiskusi dengan teman sepermainan terkait kegiatan bertani di sawah, terutama berdiskusi tentang saat mereka membantu orang tua mereka ketika panen dan berapa bayaran yang mereka terima ketika membantu orang tua mereka saat panen. Sementara itu pemuda dan pemudi di Desa Ciasmara cenderung jarang mencari informasi mengenai teknis pertanian dan melakukan kegiatan bertani bersama karena pada umumnya pemuda dan pemudi yang terlibat bertani hanya sebatas membantu orang tua saja tidak pernah bertani secara bersama-sama. Orang muda di desa masih terlibat dalam kegiatan pertanian tetapi hanya sebagai tenaga kerja dalam keluarga yang bertujuan menekan biaya produksi pertanian.

\section{Pola Sosialisasi Orang Tua}

Pola sosialisasi nilai pertanian dari orang tua kepada pemuda dan pemudi tersebut dilakukan dalam bentuk pelibatan dalam kegiatan panen dan kegiatan menanam padi (tandur) atau dalam bentuk kegiatan keluarga secara bersama atau family patterned interaction (Nugraha dan Supriatna, 2020b). Tabel 4 menunjukan bahwa orang tua menyosialisasikan nilai pertanian secara berbeda kepada pemuda dan pemudi di desa.Orang tua cenderung menyosialisasikan nilai pertanian kepada anak laki-laki (pemuda) dibandingkan anak perempuan (pemudi). Pemuda desa Ciasmara cenderung tinggi pelibatannya dalam kegiatan panen membantu orang tua sebagai family labor dengan rataan skor 2,81 sementara itu pemudi cenderung sangat rendah keterlibatannya dalam membantu orang tua dalam kegiatan panen dengan rataan skor 2,14. Salah satu orang tua yang diwawancarai menjelaskan bahwa dirinya memang tidak mau mengajak anak perempuannya untuk membantu bertani karena malu jika ada tetangga yang melihat membantu saat panen, karena pemudi biasanya hanya terlibat mengantarkan makanan atau membantu tandur. Jika dibahas secara lebih mendetail, baik pemuda dan pemudi di desa Ciasmara cenderung jarang membantu orang tua mereka dalam kegiatan mengolah lahan dan menanam (tandur), hal ini disebabkan kedua kegiatan ini membutuhan keahlian terkait dengan penggunaan traktor dan mengerti mengenai pengaturan jarak tanam ketika tandur. Sementara itu, pada indikator membantu dalam kegiatan panen, pemuda cenderung cukup sering membantu orang tua mereka dalam kegiatan panen dengan rataan skor 2,81 berbeda dengan pemudi yang jarang membantu orang tua mereka dalam kegiatan panen dengan skor 2,14.

\section{Hubungan antara Orang Tua dan Teman Sepermainan dengan Sikap Pemuda dan Pemudi terhadap pekerjaan di Sektor Pertanian.}

Tabel 5 menunjukkan bahwa aktor sosialiasi primer, dalam hal ini orang tua dan teman sepermainan memiliki peranan penting dalam membangun ketertarikan pemuda dan pemudi di desa untuk bekerja di sektor pertanian.

Tabel 5. Hubungan antara agen sosialisasi dengan sikap pemuda dan pemudi desa

\begin{tabular}{lcccccc}
\hline \multirow{2}{*}{ Aktor Sosialisasi } & \multicolumn{2}{c}{ Tingkat Kognitif } & \multicolumn{2}{c}{ Tingkat Afektif } & \multicolumn{2}{c}{ Tingkat Konatif } \\
\cline { 2 - 7 } & Pemuda & Pemudi & Pemuda & Pemudi & Pemuda & Pemudi \\
\hline Teman Sepermainan & 0,003 & $0,351^{* *}$ & 0,166 & $0,443^{* *}$ & $0,267^{*}$ & $0,430^{* *}$ \\
Orang Tua & 0,218 & $0,370^{* *}$ & $0,385^{* *}$ & $0,540^{* *}$ & $0,387^{* *}$ & $0,629^{* *}$ \\
\hline
\end{tabular}

Keterangan: * Berhubungan Signifikan, **Berhubungan Sangat Signifikan 
Orang tua memiliki peranan yang lebih kuat dibandingkan teman sepermainan dalam membangun ketertarikan pemuda dan pemudi untuk bekerja di sektor pertanian.

Orang tua memiliki posisi yang sangat penting dalam membangun identitas orang muda, salah satunya mengenai Identitas mengenai pekerjaan. Melalui pelaksanaan kegiatan bersama di sawah, orang tua menanamkan nilai-nilai mengenai pertanian, mengenai untung rugi, kendala teknis, mengenai relasi kuasa dalam pekerjaan di sektor pertanian. Hal-hal tersebut pada akhirnya membentuk preferensi apakah pemuda akan bertani atau tidak. Nilai hubungan yang positif menunjukan bahwa semakin tinggi interaksi dengan orang tua dalam kegiatan pertanian maka akan semakin baik pula sikap pemuda terhadap pekerjaan di sektor pertanian begitu pulan dengan teman sepermainan, semakin tinggi interaksi pemuda dan pemudi terhadap teman sepermainan di sektor pertanian maka akan semakin positif sikap pemuda dan pemudi terhadap pekerjaan di sektor pertanian. Nugraha (2012) menemukan temuan serupa, namun pada konteks pertanian hortikultura, temuannya menjelaskan bahwa ritual dan kegiatan bersama dalam keluarga mampu membangun nilai posistif mengenai pekerjaan pertanian. Orang muda baik pemuda dan pemudi akan melihat bahwa pertanian memiliki posisi penting dalam keberlangsungan kehidupan rumah tangga petani.

Jika dibandingkan antara pemuda dan pemudi, maka baik orang tua maupun teman sepermainan lebih memiliki hubungan yang lebih kuat dalam memengaruhi ketertarikan pemudi untuk bekerja di sektor pertanian. Hal ini disebabkan antara lain karena pemudi relatif hanya mendapatkan informasi mengenai pertanian dari orang tua dan teman sepermainan, selain itu pemudi di Desa Ciasmara cenderung mobilitasnya hanya di dalam desa sehingga pemudi tidak memiliki pandangan yang berbeda dengan orang tua dan teman sepermainan mereka terkait dengan pekerjaan di sektor pertanian. Berbeda dengan pemuda, yang mobilitasnya sampai keluar desa bahkan sampai ke kota, atau teman-teman sesame pemuda yang sudah bermigrasi ke kota terlebih dahulu untuk bekerja sebagai garmen ataupun penjual sate pikul hal ini berdampak terhadap banyaknya informasi tandingan terkait pertanian yang pemuda peroleh sehingga dalam proses internalisasi nilai-nilai pertanian sering kali pemuda memiliki pandangan yang berbeda dengan apa yang telah diajarkan oleh orang tua atau didiskusikan bersama teman - temannya atau yang disebut dengan pertarungan gagasan tentang pertanian (White, 2018). Dalam memahami pemuda kita perlu melihat juga bagaimana pemuda itu sendiri aktif sebagai agen yang membawa nilai baru dan memengaruhi nilai-nilai yang sudah ada sebelumnya.

\section{KESIMPULAN}

Terdapat perbedaan sikap antara pemuda dan pemudi terhadap pekerjaan di sektor pertanian. Pemuda memiliki sikap yang cenderung lebih positif sementara itu pemudi cenderung memiliki sikap yang negatif terhadap pekerjaan di sektor pertanian. Perbedaan tersebut karena pemuda cenderung lebih sering ikut terlibat dalam kegiatan pertanian membantu orang tua mereka sebagai tenaga kerja keluarga (family labor) sementara pemudi tidak ikut terlibat membantu orang tua mereka.

Terdapat perbedaan pola sosialisasi tentang nilai pertanian dari orang tua kepada pemuda dan pemudi. Pemuda cukup sering mendapatkan internalisasi nilai-nilai pertanian baik dari ayah dan ibu mereka ketika terlibat dalam kegiatan panen. Sementara itu pemudi cenderung jarang mendapat internalisasi nilai pertanian dari ibu tetapi tidak mendapatkan pengetahuan tentang praktik pertanian.

Orang tua merupakan aktor sosialisasi yang paling memiliki hubungan kuat dengan pembentukan sikap pemuda dan pemudi terhadap pekerjaan di sektor pertanian.Semakin tinggi interaksi antara pemuda maupun pemudi dengan orang tua mereka di sektor pertanian maka akan semakin positif sikap pemuda dan pemudi terhadap pekerjaan di sektor pertanian.

\section{DAFTAR PUSTAKA}

Akatiga, \& White, B. (2015). Would I like to be a farmer? - Inside Indonesia. In Inside Indonesia.

BPS. (2013). Pedoman Pencacah Sensus Pertanian 2013. Jakarta: BPS. 
Darling, N. (2007). Ecological systems theory: The person in the center of the vircles. Research in Human Development, 4(34), 203-217.https://doi.org/10.1080/1542 7600701663023.

Jayawinangun, R., \& Nugraha, Y. A. (2018). Penggunaan internet dan media sosial orang muda di pedesaan. Wahana, 24(2), $1-14$.

Neuman, W. L. (2014). Social Research Methods: Qualitative and Quantitative Approaches. New York: Pearson Education Limited.

Nugraha, Y. A., \& Martha, L. P. (2020). The correlation between land ownership status, parents occupation, and future of agriculture with the youth attitude who work in agricultural sector (Case of Pamijahan Sub-District, Bogor District). Buletin Penelitian Sosial Ekonomi Pertanian, 22(2), 51-57.

Nugraha, Y. A., \& Nugroho, D. R. (2019). Rural youth behavior in watching television (Case study rural youth in Ciasmara Village Pamijahan SubDistrict, Bogor Regency). Jhss (Journal of Humanities and Social Studies), 3(1), 32-36.
Nugraha, Y. A., \& Supriatna, R. A. (2020a). Peran teman sepermainan dalam membentuk sikap pemuda pedesaan terhadap pekerjaan di sektor pertanian padi (kasus pemuda di Desa Ciasmara, Kecamatan Pamijahan Kabupaten Bogor). Jurnal Ilmiah Agribisnis, 5(1), 1-10.

Nugraha, Y. A., \& Supriatna, R. A. (2020b). Pola komunikasi ritual orang tua-anak dalam pewarisan pengetahuan dan afeksi terkait pekerjaan di sektor pertanian padi. Commed : Jurnal Komunikasi Dan Media, 4(2), 208.

Supriatna, R. A., \& Nugraha, Y. A. (2020). Menguak realitas praktik sedekah bumi di Desa Ciasmara Kecamatan Pamijahan Kabupaten Bogor. Jurnal Penelitian Sosial Ilmu Komunikasi, 2(1), 43-59.

White, B. (2012). Agriculture and the generation problem: Rural youth, employment and the future of farming. IDS Bulletin, 43(6), 9-19.

White, B. (2020). IFAD Research Series 48 Rural Youth, Today and Tomorrow. In SSRN Electronic Journal. 